Reproduction

\section{Any need to revisit the male reproductive toxicity of lead?}

\section{J P Bonde, P Apostoli}

\section{Commentary on the paper by Shiau et al (Occup Environ Med, November 2004)*}

T he toxicity of lead has been known for millennia and has served as a template for toxicology studies. ${ }^{1}$ According to some 45000 measurements in European industrial settings spanning smelters, battery manufacturing, and foundries, the average concentration of lead in blood steadily declined from $68 \mu \mathrm{g} / \mathrm{dl}$ in 1970 to $35 \mu \mathrm{g} / \mathrm{dl}$ in $1995 .^{2}$ In parallel with this development the introduction of non-leaded gasoline in the late 1970s was followed by a dramatic decline in body burden of lead in the general population. ${ }^{3}$ However, unlike many other metals such as zinc, chromium, manganese, copper, and iron, lead has no known essential effects for living organisms, and current exposure levels are still high compared to pre-industrial populations. Therefore it is important to continue to control lead exposure and to unravel effects of the low and very low doses of the metal.

Lead has long been known to be toxic to male fertility. Several studies in rats and other rodents indicate that blood lead concentrations above $30-40 \mu \mathrm{g} / \mathrm{dl}$ are associated with impairment of spermatogenesis and reduced concentrations of androgens-although some rat species and strains seem quite resistant. ${ }^{4}$ The latter could be due to differences in tissue distribution. Contrary to findings in small rodents, a comprehensive study in rabbits estimated a threshold for reduced sperm count of $24 \mu \mathrm{g} / \mathrm{dl}$ and even lower for a range of other semen characteristics. ${ }^{5}$ Male reproductive toxicity studies in humans have addressed effects on sex hormone levels, ${ }^{67}$ birth rates, ${ }^{8-10}$ time taken to conceive in couples not using contraception, ${ }^{11-13}$ and semen characteristics. ${ }^{14-19}$ Although findings across studies and endpoints are not entirely consistent, the main body of evidence points to current blood lead concentrations of about 40-50 $\mu \mathrm{g}$ / $\mathrm{dl}$ as a most likely no adverse effect threshold. This applies to semen characteristics such as sperm count, sperm

*Shiau C-Y, Wang J-D, Chen P-C. Decreased fecundity among male lead workers. Occup Environ Med 2004:61:915-23. motility, and abnormal sperm forms, as well as to fertility rate and time taken to conceive, whereas primary effects on the hormonal regulation of the male reproductive system at these exposure levels are questionable.

This view on male reproductive toxicity of lead is challenged by the findings on decreased fecundity among male lead workers published by Shiau et al in the November 2004 issue of this journal. ${ }^{20}$ Using the time to pregnancy methodology, they observed an astonishing clear exposure response relation between current blood lead level and time taken to conceive among male battery workers in Taiwan. The fecundability ratio, which estimates the probability of conception in a menstrual cycle in exposed compared to nonexposed, declined steadily from 0.9 in men with blood lead levels below $20 \mu \mathrm{g} /$ $\mathrm{dl}$ to 0.4 among men with a blood level above $40 \mu \mathrm{g} / \mathrm{dl}$. These findings are divergent from the results in a few earlier time to pregnancy studies in lead exposed workers. ${ }^{132122}$ Close scrutiny does not reveal artifacts of design or research methodology, although a rather small sample size, few men in each exposure category, and time varying fecundability ratios adds to the limitations of this study. We must acknowledge several inherent limitations of retrospective time to pregnancy studies based on samples of women with recognised pregnancies. For instance, the time or the number of menstrual cycles taken to conceive is only defined for planned pregnancies. Accidental (unplanned) pregnancies are related to fecundity and could be associated with behavioural and lifestyle factors, and indirectly with occupational exposure. Various contraceptive methods are not equally effective and may not be used rigorously over time, which may blur the distinction between protected and unprotected cycles. Similarly, fecundability is strongly dependent on frequency and timing of sexual intercourse, which cannot reliably be determined in retrospective studies. However, many of these uncertainties most likely will result in failure to detect true effects. The fact that a large European study failed to show effects of lead on time to pregnancy in any of three independent study populations ${ }^{12}$ is not reassuring if the consistency of findings across countries reflects repetition of errors inherent in the study design. The divergent findings in Europe and Taiwan could of course also be due to differences in susceptibility to the toxic effects of lead, such as the well known higher toxicity of several organic solvents in Asian workers.

But are the findings of Shiau et al not in conflict with the semen studies? Several cross sectional studies of worker populations do not reveal effects of blood lead at levels below $40-50 \mu \mathrm{g} / \mathrm{dl}$ on sperm concentration or sperm count. And semen characteristics are considered more sensitive indicators of male fecundity than functional measures such as time to pregnancy. ${ }^{23}$ Obviously the answer to this question depends on the site of action and the mechanism of the reproductive toxicity of lead. Reproductive effects at low exposure levels could bypass detection by crude semen characteristics. During recent years it has been shown that lead may interfere with the reorganisation and tight packaging of sperm DNA during spermatogenesis-the chromatin condensation-by competition with zinc on protamin binding sites. ${ }^{24}$ This results in reduced stability of the chromatin, and abnormal chromatin structure is strongly related to reduced fertility in humans. ${ }^{26}$ And there is indeed limited evidence that chromatin structure abnormalities are related to lead exposures in the lower range of blood lead values in men with high concentrations of lead within spermatozoa. ${ }^{16}$ Other mechanisms might be of significance as well. Thus it was recently found that lead at environmental levels strongly interferes with the sperm acrosome reaction, which is essential for fertilisation and negatively affects outcomes of artificial insemination. ${ }^{27}$

If the findings of Shiau and co-workers are corroborated in independent studies, it may have profound implications for worker safety programmes, even at present day lower exposure levels. In addition to studies using functional measures of fertility, it is warranted to undertake semen studies with assessment of lead close to the target organ-firstly in spermatozoaand to include measurements of chromatin structure and acrosome reactions as endpoints. In our opinion the study from Taiwan does not present data sufficient to modify the main conclusions from the European studies on effects of lead on male fertility, but 
there is definitely a need to keep open this line of research.

Occup Environ Med 2005;62:2-3.

doi: 10.1136/oem.2004.016543

\section{Authors' affiliations}

J P Bonde, Department of Occupational Medicine, Aarhus University Hospital, Denmark

P Apostoli, Institute of Occupational Medicine and Industrial Hygiene, University of Brescia, Italy

Correspondence to: Professor J P Bonde, Department of Occupational Medicine, Aarhus University Hospital, Noerrebrogade 44, build. 2C, DK-8000 Aarhus C, Denmark; ipbon@ akh.aaa.dk

\section{REFERENCES}

1 Silbergeld EK. Toward the twenty-first century: lessons from lead and lessons yet to learn. Environ Health Perspect 1990;86:191-6.

2 Bonde JP, Joffe M, Danscher G, et al. Objectives, designs and populations of the European Asclepios study on occupational hazards to male reproductive capability. Scand J Work Environ Health 1999;25(suppl 1):49-61 (discussion 76-8).

3 Landrigan PJ. The worldwide problem of lead in petrol. Bull World Health Organ 2002;80:768

4 Apostoli P, Kiss P, Porru S, et al. Male reproductive toxicity of lead in animals and humans. ASCLEPIOS Study Group. Occup Environ Med 1998;55:364-74.
5 Moorman WJ, Skaggs SR, Clark JC, et al. Male reproductive effects of lead, including species extrapolation for the rabbit model. Reprod Toxicol 1998;12:333-46.

6 Cullen J, Fuller R, Dolphin C. Endocrine stress responses of drivers in a 'real-life' heavy-goods vehicle driving task. Psychoneuroendocrinology 1979;4:107-15.

7 Gustafson Å, Hedner P, Schutz A, et al. Occupational lead exposure and pituitary function. Int Arch Occup Environ Health 1989;61:277-81.

8 Bonde JP, Kolstad H. Fertility of Danish battery workers exposed to lead. Int J Epidemiol 1997;26:1281-8.

9 Coste J, Mandereau L, Pessione F, et al. Leadexposed workmen and fertility: a cohort study on 354 subjects. Eur J Epidemiol 1991;7:154-8.

10 Gennart JP, Buchet JP, Roels H, et al. Fertility of male workers exposed to cadmium, lead, or manganese 19. Am J Epidemio 1992;135:1208-19.

11 Apostoli P, Bellini A, Porru S, et al. The effect of lead on male fertility: a time to pregnancy (TTP) study. Am J Ind Med 2000;38:310-15.

12 Joffe M, Bisanti L, Apostoli P, et al. Time to pregnancy and occupational lead exposure. Occup Environ Med 2003;60:752-8.

13 Sallmen M, Lindbohm ML, Anttila A, et al. Time to pregnancy among the wives of men occupationally exposed to lead. Epidemiology 2000;11:141-7.

14 Alexander BH, Checkoway $\mathrm{H}$, van Netten $\mathrm{C}$, et al. Semen quality of men employed at a lead smelter. J Occup Med 1996;53:41 1-16.

15 Assennato G, Paci C, Baser ME, et al. Sperm count suppression without endocrine dysfunction in lead-exposed men. Arch Environ Health 1986;41:387-90.

16 Bonde JP, Joffe $M$, Apostoli $P$, et al. Sperm count and chromatin structure in men exposed to inorganic lead: lowest adverse effect levels. Occup Environ Med 2002;59:234-42.
17 Lerda D. Study of sperm characteristics in persons occupationally exposed to lead. Am J Ind Med 1992:22:567-71.

18 Viskum S, Rabjerg L, Jorgensen PJ, et al Improvement in semen quality associated with decreasing occupational lead exposure. Am J Ind Med 1999;35:257-63.

19 Wildt K, Eliasson R, Berlin M. Effect of occupational exposure to lead on sperm and semen. Reproductive and Developmental Toxicity of Metals 1983:279-300

20 Shiau C-Y, Wang J-D, Chen P-C. Decreased fecundity among male lead workers. Occup Environ Med 2004:61:915-23.

21 Joffe M, Bisanti L, Apostoli $P$, et al. Time to pregnancy and occupational lead exposure. Asclepios. Scand J Work Environ Health 1999-25(suppl 1):64-5 (discussion 76-8)

22 Sallmen $M$. Exposure to lead and male fertility. Int $J$ Occup Med Environ Health 2001;14:219-22.

23 Bonde JP, Hiollund $\mathrm{NH}$, Kolstad $\mathrm{HA}$, et al. Environmental semen studies - is infertility increased by a decline in sperm count? Scand J Work Environ Health 1999;25(suppl 1):12-16 (discussion 76-8).

24 Quintanilla-Vega B, Hoover D, Bal W, et al. Lead effects on protamine-DNA binding. Am J Ind Med 2000;38:324-9

25 Quintanilla-Vega B, Hoover DJ, Bal W, et al. Lead interaction with human protamine (HP2) as a mechanism of male reproductive toxicity. Chem Res Toxicol 2000; 13:594-600.

26 Spano M, Kolstad H, Larsen SB, et al. Flow cytometric sperm chromatin structure assay as an independent descriptor of human semen quality. Scand J Work Environ Health 1999:25(suppl 1):28-30 (discussion 76-8)

27 Benoff S, Hurley IR, Millan C, et al. Seminal lead concentrations negatively affect outcomes of artificial insemination. Fertil Steril 2003;80:517-25.

\section{OEM EDITORIAL BOARD MEETING}

\section{November 2004}

7 2004 meeting of the $O E M$ Editorial Board was held on Wednesday, 10 November 2004 at BMA House, London. The photo shows some of the Board Members and Editorial Staff.

Other Editorial Board Members are: Anders Ahlbom, Harvey Checkoway, Francesco Forastiere, Timo Kauppinen, Robert Maynard, Laura Punnett, Stephen Rappaport, and David Snashall.

Front row, left to right: David Koh, Andy Fosberry, Manolis Kogevinas, Peter Westerholm, Dana Loomis, Keith Palmer, Harry Roels, Kathryn Walsh.

Back row, left to right: Craig Jackson, Malcolm Sim, Roseanne McNamee, Dick Heederik Mark Neuwenhuijsen, Harry Shannon, Hans Kromhout, Rachel Harvey.

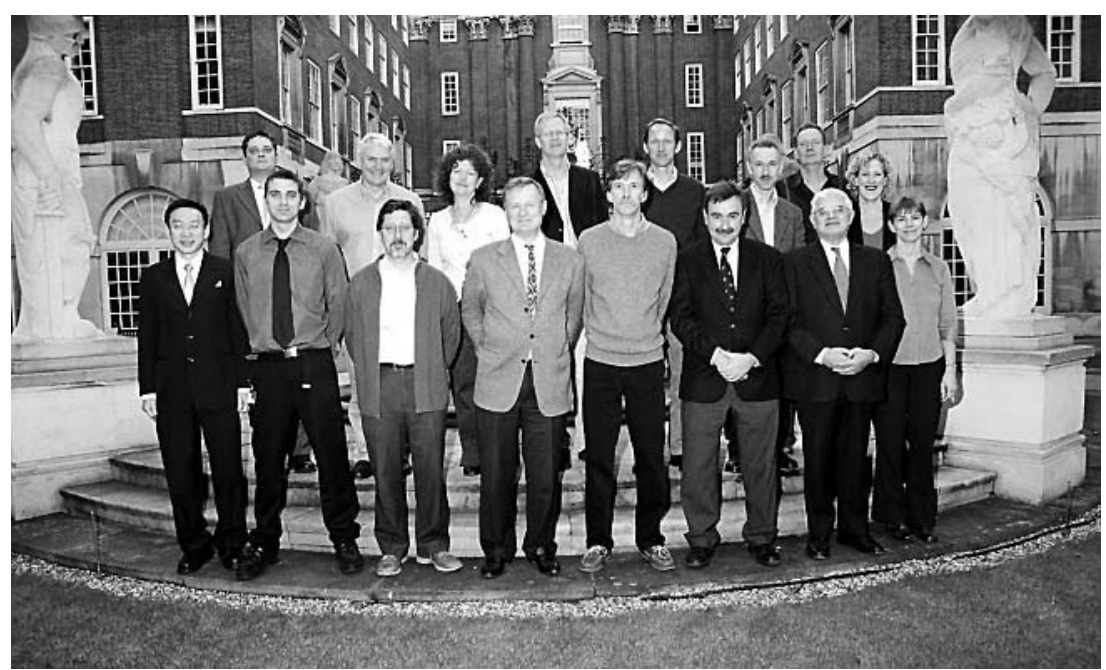

